\title{
Thyroid dysfunction in hyperemesis gravidarum: a study in Turkish pregnant women
}

\section{Hiperemezis gravidarumda tiroid disfonksiyonu: Türk gebelerde yapılan bir çalışma}

\author{
Nermin Akdemir ${ }^{1}$, Cemil Bilir ${ }^{2}$ \\ 'Department of Gynecology and Obstetrics, Keçiören Teaching and Research Hospital, Ankara, Turkey \\ ${ }^{2}$ Department of Internal Medicine, Faculty of Medicine, Zonguldak Karaelmas Universtiy, Zonguldak, Turkey
}

\section{Abstract}

Objective: In this study we investigate the possible relation of thyroid dysfunction and thyroid antibodies to hyperemesis gravidarum.

Material and Methods: Thirty-seven patients with hyperemesis gravidarum and 33 healthy controls have been included in this study. Results: Thyroid dysfunction was significantly more common than in controls ( $38 \%$ vs $6 \%, \mathrm{p}=0.002$ ). Thyroglobulin antibodies were also significantly more common in patients with hyperemesis gravidarum than controls $(54 \mathrm{IU} / \mathrm{mL}$ vs. $14 \mathrm{IU} / \mathrm{mL}, \mathrm{p}=0.03)$.

Conclusion: Hyperemesis gravidarum can be a risk factor for postpartum thyroid dysfunction. Thyroid antibodies must be checked in the hyperemesis population in an endemic goitre region and/or iodine replacement regions. (J Turkish-German Gynecol Assoc 2011; 12: 140-3)

Key words: Hyperemesis gravidarum, thyroid function

Received: 26 March, 2011

Accepted: 13 May, 2011

\section{Introduction}

Hyperemesis gravidarum was defined as persistent vomiting accompanied by weight loss of at least $5 \%$ of pre- pregnancy body weight and/or ketonuria unrelated to other causes and requiring hospital admission for severe vomiting causing dehydration $(1,2)$. The pathogenesis of hyperemesis is unknown. Usually it is difficult to differentiate from the nausea and vomiting such as morning sickness from the HG, which affects $80 \%$ of pregnancies (3). Some hormonal changes determined in $\mathrm{HG}$; elevated serum concentrations of estrogen and progesterone levels implicated in the pathogenesis of this disorder, serum human chorionic gonadotropin (hCG) concentration is higher in women with HG women also supports a possible etiologic role for this hormone. In addition, hCG has a thyroid-stimulating activity (4-6). Higher hCG levels in women with HG and a positive correlation between hCG levels and the severity of vomiting and degree of thyroid stimulation was established previously (7). Hyperthyroidism is possibly due to high serum concentrations of hCG which has a thyroid-stimulating activity (5). One study showed that low serum TSH concentrations are seen more often in
Özet

Amaç: Bu çalışmadaki amacımız tiroid fonksiyon bozuklukları ve tiroid antikorları ile hiperemezis gravidarum arasındaki olası ilişkiyi araştırmaktı.

Gereç ve Yöntemler: Hiperemezis gravidarumu olan 37 hasta ve 33 sağlıklı kontrol gurubu çalışmada incelendi.

Bulgular: Tiroid disfonksiyon sıklığı hiperemezis gravidarumda kontrol grubuna göre anlamlı olarak daha fazla bulundu (\%38'e \%6, $p=0.002$ ). Anti-tiroglobulin düzeyleride anlamlı olarak kontrol grubundan daha yüksekti ( $54 \mathrm{IU} / \mathrm{mL} e .14 \mathrm{IU} / \mathrm{mL}, \mathrm{p}=0.03$ ).

Sonuçlar: Hiperemezis gravidarum postpartum tiroid fonksiyon bozuklukları için bir risk faktörü olabilir. Tiroid antikor düzeyleri de özellikle endemik guatr ve/veya iyot replasmanı yapılan bölgedeki gebelerde de mutlaka bakılmalıdır. (J Turkish-German Gynecol Assoc 2011; 12: 140-3)

Anahtar kelimeler: Hiperemezis gravidarum, tiroid fonksiyonu

Geliş Tarihi: 26 Mart 2011

Kabul Tarihi: 13 Mayss 2011

women with HG than in normal pregnant women; TSH was suppressed in 60 percent of hyperemesis patients versus 9 percent of controls (8). In the literature there are insufficient studies which have investigated the thyroid antibodies in HG. In this study we investigate the possible relation of thyroid antibodies to hyperemesis gravidarum.

\section{Method}

\section{Patients}

Thirty-seven patients with hyperemesis gravidarum and 33 healthy controls have been evaluated in this study. We have chosen the control group as a gestational age matched control. The study protocol was approved by the Ankara Kecioren Education and Research Hospital. Written, informed consent was obtained from all patients which also adhered to the principles of the Helsinki Declaration. The study cohort has been selected from a gynecological outpatient population of a Research Hospital between June 2009 to May 2010.

\section{Clinical Assessment}

Hyperemesis gravidarum, defined as persistent vomiting accompanied by weight loss of at least $5 \%$ of pre- pregnancy

Address for Correspondence: Cemil Bilir M.D., Sultan Orhan Mah., 1145 Sok., No: 14/2 Gebze, Kocaeli, Turkey

Phone: +905052014666 Fax: +902626461503 e.mail: cebilir@yahoo.com

(C) Copyright 2011 by the Turkish-German Gynecological Education and Research Foundation - Available on-line at www.jtgga.org doi:10.5152/jtgga.2011.33 
body weight and/or ketonuria unrelated to other causes and requiring hospital admission for severe vomiting causing dehydration (2). The control group did not have any symptoms or only mild nausea without vomiting. Patients or controls with molar pregnancy, multiparity, coronary heart disease, diabetes, hypertension or any chronic disease using medication were not included in the study. Fasting (8 hours) blood samples were taken in the morning from each patient and were centrifuged for $5 \mathrm{~min}$ at $3.000 \mathrm{~g}$ and stored at $-80^{\circ} \mathrm{C}$ until the time of analysis. Blood glucose, serum creatinine, blood urea nitrogen, aspartate and alanine aminotransferases, sodium, potassium and calcium electrolytes were measured using an automatic analyzer (Konelab 60i, Thermo Scientific, Finland). Serum thyroid stimulating hormone and free thyroid hormones were analyzed by UniCel DxI 800 Access Immunoassay System (Beckman Coulter, USA). Complete blood counts were measured using a Coulter LH 500 hematology analyzer (Beckman Coulter, USA). Thyroglobulin antibody (Anti-Tg) and thyroperoxidase antibody (TPO-Ab) Liason analyzer systems manufacturered by Diasosin, STILLWATER, MN 55082, USA were used.

Ultrasound exams were performed by the same radiologist blinded to the clinical characteristics of the patients.

Patients admitted to the hospital were intravenously hydrated followed by reintroduction of oral intake. Dehydration was supplemented with appropriate electrolytes, vitamins and metoclopramide (5 to $10 \mathrm{mg}$ ) as needed. Normal values of hormones were; TSH (0.3-4.2 mIU/L), fT3 (2.2-4.2pg/mL), fT4 (0.65$1.7 \mathrm{ng} / \mathrm{mL})$, Thyroglobulin antibody/antiTG (5-100 IU/mL) and thyroperoxidase antibody/TPO-Ab (1.16 IU/mL). Upper limits of the reference values were accepted as positive.

Thyroid dysfunctions were defined as $(5,8)$;
- Lower TSH values with or without abnormal thyroid antibodies and/or free thyroid hormone levels.

- Higher TSH values with or without abnormal thyroid antibodies and/or free thyroid hormone levels.

\section{Statistical analysis}

Shapiro-Wilk test was used to identify the data distribution. Normally distributed data were presented as mean (SD) for baseline and descriptive statistics, and median and interquartile range for non-normally distributed data. Data with normal distribution were analyzed using unpaired t test. Mann-Whitney $\mathrm{U}$ test was used for analyzing abnormally distributed data. Positive and negative values were compared by chi-square test. All $P$ values were calculated as two-tailed. $\mathrm{p}<0.05$ was set as statistically significant. SPSS 15.0 was used for statistical calculations (SPSS Inc., Chicago, IL, USA).

\section{Results}

Baseline clinical and laboratory characteristics of the patients and controls are presented in Table 1. Groups were similar in age, weight, gestational week, hemoglobin, creatinine and glucose levels. No patients or controls had any other systemic disease or any medication. The hyponatremia frequency in $\mathrm{HG}$ group was $24 \%$ which was significantly higher than the $3 \%$ of hyponatremia in the control group $(p=0.005)$. AST levels were significantly elevated in the HG group compared to the controls $(18 \pm 7.5 \mathrm{u} / \mathrm{L}$ versus $17 \pm 3 \mathrm{u} / \mathrm{L}, \mathrm{p}: 0.01)$. ALT levels were also significantly higher in the $\mathrm{HG}$ group than the controls $(18 \pm 14 \mathrm{u} / \mathrm{L}$ versus $14 \pm 4 \mathrm{u} / \mathrm{L}, \mathrm{p}=0.04)$. Also the $\mathrm{HG}$ group had lower levels of TSH, p values were 0.03 . HG patients had significantly higher

Table 1. Baseline clinical and laboratory characteristics of 37 patients with hyperemesis gravidarum, dysmenorrhea and 33 healthy pregnant controls

\begin{tabular}{|l|c|c|c|}
\hline & Patients (n=37) & Controls (n=33) & 0.36 \\
\hline Age, years & $25.4( \pm 5.2)$ & $25.3( \pm 4.5)$ & 0.73 \\
\hline Gestation, week & $9.7( \pm 2.2)$ & $10( \pm 2.2)$ & 0.34 \\
\hline Weight, kg & $63( \pm 11)$ & $62( \pm 9)$ & 0.74 \\
\hline Creatine & $0.65( \pm 0.1)$ & $0.61( \pm 0.1)$ & 0.33 \\
\hline Hgb, g/dL & $12( \pm 0.9)$ & $11.7( \pm 1)$ & 0.056 \\
\hline Plt, $\mathrm{x} 103 \mu \mathrm{L}$ & $234( \pm 67)$ & $226( \pm 48)$ & 0.75 \\
\hline Glucose, mg/dL & $85( \pm 8)$ & $86( \pm 8)$ & 0.005 \\
\hline BUN, mg/100 ml & $20( \pm 6.3)$ & $16( \pm 3.3)$ & 0.01 \\
\hline AST, $\mathrm{u} / \mathrm{L}$ & $18( \pm 7.5)$ & $17( \pm 3)$ & 0.04 \\
\hline ALT, $\mathrm{u} / \mathrm{L}$ & $18( \pm 14)$ & $14( \pm 4)$ & 0.005 \\
\hline Sodium, mEq/L & $135( \pm 2.7)$ & $136( \pm 1.7)$ & 0.9 \\
\hline Potassium, mEq/L & $3.9( \pm 0.3)$ & $3.7( \pm 0.2)$ & 0.03 \\
\hline TSH, mIU/l & $0.95( \pm 0.56)$ & $1.4( \pm 1.15)$ & 0.07 \\
\hline fT3, $\mathrm{pg} / \mathrm{mL}$ & $2.86( \pm 0.46)$ & $2.6( \pm 0.3)$ & 0.02 \\
\hline fT4, ng/mL & $1.07( \pm 0.3)$ & $0.89( \pm 0.17)$ & \\
\hline AntiTg, IU/mL, IR & & & \\
\hline
\end{tabular}


Table 2. Thyroid Dysfunctions in HG and control group

\begin{tabular}{|l|c|c|c|c|}
\hline & $\begin{array}{c}\text { Decreased TSH } \\
(<\mathbf{0 . 3 m i u} / \mathbf{L})\end{array}$ & $\begin{array}{c}\text { Positive AntiTG } \\
(>\mathbf{1 0 0 I U / m L})\end{array}$ & $\begin{array}{c}\text { Positive TPO-Ab } \\
(>\mathbf{1 6 I U} / \mathbf{m L})\end{array}$ & $\begin{array}{c}\text { p value } \\
(\mathbf{C h i}-S q u a r e)\end{array}$ \\
\hline Hyperemesis (n:37) & $3(8 \%)$ & $9(24 \%)$ & $2(5.5 \%)$ & \\
\hline Control (n:33) & 0 & 0 & $2(6 \%)$ & 0.002 \\
\hline Total (n:70) & 3 & 9 & 4 & 0 \\
\hline
\end{tabular}

levels of freeT4, but all values were within the normal reference range of our laboratory. AntiTG titers were significantly higher than controls in the HG group ( $54 \mathrm{IU} / \mathrm{mL}$ vs. $14 \mathrm{IU} / \mathrm{mL}, \mathrm{p}=0.03$ ) but TPO-Ab were not. In the HG group 9 (24\%), patients had positive antiTG but thecontrol group did not $(p=0.007)$. There was no significant difference between the two groups of TPO$\mathrm{Ab}(\mathrm{p}=0.9)$. Lower TSH with normal free thyroid hormone level was determined in 3 patients in the HG group. Neither hyperthyroid nor hypothyroid pregnant women had clinical symptoms so they were not given any antithyroid medication. When we evaluate the all thyroid dysfunctions (only lower TSH with normal freeT3/T4, positive TPO-Ab with negative anti-Tg and positive anti-Tg with negative TPO-Ab) 14 (38\%) patients in the HG group and $2(6 \%)$ in the control group $(p=0.002)$ are also presented in Table 2. In patients who had thyroid dysfunction, thyroid stimulating antibodies were negative. There is no correlation between the anti TG, TPO-Ab, TSH, freeT3 and free T4. All the study population had normal thyroid on physical examination.

\section{Discussion}

Results from this study showed for the first time that thyroglobulin antibody concentrations are significantly higher in the HG group compared to healthy pregnant controls. Also hyperemetic pregnant women had significantly higher (38\% vs. $6 \%$, p: 0.002) thyroid dysfunctions than controls.

Thyroid functions change in pregnancy, especially within the first trimester, in general because of estrogen-induced increases in serum thyroxine-binding globulin (TBG) levels and human chorionic gonadotropin (hCG) induced increases in thyroid hormone synthesis and release (9). Most prospective studies which compared TSH and T4 levels of HG patients with the controls showed significantly lower levels of TSH and significantly higher levels of T4 titers. Also there is a relationship between hyperthyroidism and severity of HG but the exact role is not yet known $(10,11)$. In our study, we found $8 \%$ subclinical hyperthyroidism but there was no correlation between the TSH and HG severity. These rates are lower than previous studies carried out in other populations. Also we found hyponatremia and elevated ALT/ AST significantly different, but at lower rates than the previous studies. However, this is one of several studies carried out on the Turkish pregnant population.

The prevalence of anti-thyroid antibodies (ATA) has been reported as $15-20 \%$ in normal pregnant women, and anti TPO antibodies were found to have a significant association with recurrent miscarriage. Therefore, the prognostic value of ATA remains uncertain $(12,13)$. Our control group had only $6 \%$ ATA but the HG group had $30 \%$ ATA. Pearce et al found that $12.4 \%$ elevated TPO$\mathrm{Ab}$ in pregnant which was higher than our study population for TPO-Ab (9). The presence of measurable maternal thyroid antibodies can be a risk factor for postpartum thyroiditis, miscarriage and premature birth. In fact, findings from a recent study suggest that treatment of TPO-Ab-positive euthyroid women with levothyroxine results in improved obstetric outcomes (9, 14-17). Propylthiouracil can provide relief of symptoms of HG. In our population hyperemesis gravidarum can be a risk factor for postpartum thyroid hyperemesis, so it should be suggested that the thyroid antibodies should be checked in the HG population in an endemic goiter region and/or iodine replacement regions like Turkey.

In this study we did not follow up the pregnant patients after delivery so we could not report the pregnancy outcomes of HG patients.

In conclusion, this is the first study of Turkish HG women in whom a significantly elevated percentage of thyroid dysfunction, especially thyroglobulin antibodies, compared to controls was found.

\section{Conflict of interest}

No conflict of interest was declared by the authors.

\section{References}

1. Bailit JL. Hyperemesis garvidarum:epidemiologic findings from a large cohort. Am J Obstet Gynecol 2005; 193: 811-4. [CrossRef]

2. Goodwin TM. Hyperemesis gravidarum. Clin Obstet Gynecol 1998; 41: 597-605. [CrossRef]

3. Gadsby R, Barnie-Adshead AM, Jagger C. A prospective study of nausea and vomiting during pregnancy. Br J Gen Pract 1993;43:245-8.

4. Lagiou P, Tamimi R, Mucci LA, Trichopoulos D, Adami HO, Hsieh CC. Nausea and vomiting in pregnancy in relation to prolactin, estrogens, and progesterone: a prospective study. Obstet Gynecol 2003; 101: 639-44. [CrossRef]

5. Kimura M, Amino N, Tamaki H, Ito E, Mitsuda N, Miyai K, Tanizawa O. Gestational thyrotoxicosis and hyperemesis gravidarum: possible role of hCG with higher stimulating activity. Clin Endocrinol (Oxf) 1993; 38: 345-50. [CrossRef]

6. Yamazaki K, Sato K, Shizume K, Kanaji Y, Ito Y, Obara T, Nakagawa T, Koizumi T, Nishimura R. Potent thyrotropic activity of human chorionic gonadotropin variants in terms of $125 \mathrm{I}$ incorporation and de novo synthesized thyroid hormone release in human thyroid follicles. J Clin Endocrinol Metab 1995; 80: 473-9. [CrossRef]

7. Tan JY, Loh KC, Yeo GS, Chee YC. Transient hyperthyroidism of hyperemesis gravidarum. BJOG: An International Journal of Obstetrics and Gynaecology 2002; 109: 683-8. [CrossRef]

8. Goodwin TM, Montoro M, Mestman JH, Pekary AE, Hershman JM. The role of chorionic gonadotropin in transient hyperthyroidism of hyperemesis gravidarum. J Clin Endocrinol Metab 1992; 75: 1333-7. [CrossRef] 
9. Pearce EN, Oken E, Gillman MW, Lee SL, Magnani B, Platek D, Braverman LE. Association of first-trimester thyroid function test values with thyroperoxıdase antibody status, smoking, and multivitamin use. Endocr pract 2008; 14: 33-9.

10. Verberg MF, Gillott DJ, Al-Fardan N, Grudzinskas JG. Hyperemesis gravidarum, a literature review. Hum Reprod Update 2005; 11 : 527-39. [CrossRef]

11. Ertekin AA, Müngen E, Yergök YZ, Ergür AR, Tütüncü L, Yıldırım İ. Hiperemezis Gravidarumda Tiroid Fonksiyonları. Turkiye Klinikleri J Gynecol Obst 1998; 8: 17-20.

12. Marai I, Carp HJA, Shai S, Shabo R, Fishman G, Shoenfeld Y. Autoantibody panel screening in recurrent miscarriages. Am J Reprod Immunol 2004; 51: 235-40. [CrossRef]

13. Carp HJ, Meroni PL, Shoenfeld Y. Autoantibodies as predictors of pregnancy complications. Rheumatology 2008; 47: 6-8. [CrossRef]
14. Stagnaro-Green A, Roman SH, Cobin RH, el-Harazy E, Wallenstein $\mathrm{S}$, Davies TF. A prospective study of lymphocyte-initiated immunosuppression in normal pregnancy: evidence of a T-cell etiology for postpartum thyroid dysfunction. J Clin Endocrinol Metab 1992; 74: 645-53. [CrossRef]

15. Prummel MF, Wiersinga WM. Thyroid autoimmunity and miscarriage. Eur J Endocrinol 2004; 150: 751-5. [CrossRef]

16. Casey BM, Dashe JS, Wells CE, McIntire DD, Byrd W, Leveno KJ, Cunningham FG. Subclinical hypothyroidism and pregnancy outcomes. Obstet Gynecol 2005; 105: 239-45. [CrossRef]

17. Negro R, Formoso G, Mangieri T, Pezzarossa A, Dazzi D, Hassan $\mathrm{H}$. Levothyroxine treatment in euthyroid pregnant women with autoimmune thyroid disease: effects on obstetrical complications. J Clin Endocrinol Metab 2006; 91: 2587-91. [CrossRef] 